\title{
Vitamin D Receptor Gene Polymorphisms in Rheumatoid Arthritis
}

\author{
Romatoid Artritte D Vitamini Reseptörü Geni Polimorfizmleri \\ Ömer ATEŞ, ${ }_{1}$ Bilgen DÖLEK, ${ }^{2}$ Levent DALYAN, ${ }^{3}$ Ayşegül Topal-SARIKAYA ${ }^{3}$ \\ ${ }^{1}$ Department of Medical Biology, Medical Faculty of Gaziosmanpaşa University, Tokat, Turkey; \\ ${ }^{2}$ Department of Molecular Genetics, Düzen Laboratory, İstanbul, Turkey; \\ ${ }^{3}$ Departments of Molecular Biology and Genetics, İstanbul University, İstanbul, Turkey
}

\begin{abstract}
Objectives: In this study, we investigated the association of Bsml, Taql, and Fokl polymorphisms in the vitamin $D$ receptor gene in rheumatoid arthritis patients with rheumatoid factor positivity and erosive disease of rheumatoid arthritis.
\end{abstract}

Patients and methods: In this study we analyzed Bsml, Taql and Fokl polymorphisms in the vitamin $D$ receptor gene in 98 patients with RA (78 females, 20 males; mean age $50.8 \pm 12.3$ years; range 38 to 63 years) and 122 healthy subjects (96 females, 26 males; mean age $57.1 \pm 6.1$ years; range 51 to 63 years) by a polymerase chain reaction followed by enzymatic digestion between May 2006 and April 2008.

Results: The distributions of Bsml, Taql and Fokl, alleles/genotypes frequencies were similar in patients and controls. There were no significant differences between the vitamin $\mathrm{D}$ receptor genotypes/alleles and the presence or absence of erosions and rheumatoid factor.

Conclusion: Our findings suggest that vitamin D receptor polymorphisms do not play a role in either rheumatoid arthritis susceptibility or in rheumatoid factor positivity and erosive disease of rheumatoid arthritis in the Turkish population.

Key words: Polymorphism; rheumatoid arthritis; vitamin D receptor.

Rheumatoid arthritis (RA) is a chronic inflammatory disease characterized by a distinctive pattern of joint involvement and joint destruction. Rheumatoid arthritis pathogenesis involves both genetic and environmental factors, but the complete etiological
Amaç: Bu çalışmada, romatoid artritli hastalarda $D$ vitamini reseptörü genindeki Bsml, Taql ve Fokl polimorfizmleri ile romatoid faktör pozitifliliği ve erozivite arasındaki ilişki araştıııldı.

Hastalar ve yöntemler: Bu çalışmada Mayıs 2006 Nisan 2008 tarihleri arasında 98 romatoid artritli hasta (78 kadın, 20 erkek; ort. yaş $50.8 \pm 12.3$ yıl; dağılım $38-63$ yıl) ve 122 sağlıklı bireyde (96 kadın, 26 erkek; ort. yaş 57.1 \pm 6.1 yıl; dağılım 51-63 yıl), D vitamini reseptörü genindeki Bsml, Taql ve Fokl polimorfizmleri-polimeraz zincir reaksiyonu ve bunu takiben enzim kesim yöntemleri kullanılarak analiz edildi.

Bulgular: Hastalarda ve kontrollerde Bsml, Taql ve Fokl allel ve genotip frekansları benzer oranlarda idi. D vitamini reseptörü genotip ve alleli frekansları ile romatoid faktör pozitifliği ve erozivite arasında anlamlı fark bulunmadı.

Sonuç: Bulgularımız Türk toplumunda D vitamini reseptörü polimorfizmlerinin hem romatoid artrite yatkınlıkta hem de romatoid faktör pozitifliğinde ve romatoid artritin eroziv hastalık oluşumunda rol oynamadığını göstermektedir.

Anahtar sözcükler: Polimorfizm; romatoid artrit; vitamin D reseptör.

picture remains unclear. The genetic basis of RA is quite complex. Genetic factors contribute 50 to $60 \%$ to the risk of developing RA. ${ }^{[1]}$

Vitamin D (VD) is a potent regulator of calcium homeostasis and plays a role in immune regulation 
and inflammation. ${ }^{[2,3]}$ A significant association between VD insufficiency and an increased incidence of autoimmune disorders has been determined. ${ }^{[4]}$ In addition, a significant clinical improvement was shown in the VD- treated patients with RA. ${ }^{[5]}$ Vitamin $\mathrm{D}$ receptor (VDR) has been demonstrated in the rheumatoid synovium and sites of cartilage erosion in patients with RA. ${ }^{[4]}$ Vitamin D receptor agonists have a critical physiological role in the regulation of the immune system. ${ }^{[6,7]}$ The role of VDR polymorphisms in RA has been studied by several investigators. There are controversial results in various reports due to ethnicities, extensive geographic variations and possibly study designs. ${ }^{[8-12]}$

There is no data on frequencies of VDR polymorphisms in Turkish patients with RA. In this study, we aimed to investigate the association of BsmI, TaqI, and FokI polymorphisms in the VDR gene in RA patients with rheumatoid factor (RF) positivity and erosive disease of RA.

\section{PATIENTS AND METHODS}

\section{Patients}

We studied VDR genetic polymorphisms in 98 RA patients (78 females and 20 males; mean age 50.8 \pm 12.3 years; range 38 to 63 years) and 122 healthy hospital workers (96 females and 26 males; mean age 57.1 \pm 6.1 years; range 51 to 63 years) who had taken part in our previous studies. ${ }^{[13,14]}$ All patients were registered at the outpatient clinic of İstanbul University, Cerrahpaşa Medical Faculty, Rheumatology Department, and they fulfilled the American College of Rheumatology (ACR) classification criteria for the diagnosis of RA. ${ }^{[15]}$ In general, patients with elevated RF and anti-cyclic citrullinated peptide (anti-CCP) have more severe disease. Although it is known that anti-CCP is more sensitive and has a more specific parameter than RF, we have only the RF results as a part of our previous study. Rheumatoid factor was known in $92 \mathrm{RA}$ patients and, among these, 58 (63\%) had positive RF. Hand and feet X-rays were available in 74 of the patients and, among these, 51 (69\%) had erosions. The healthy group had no history of any rheumatologic disorder. This study protocol was approved by the Ethics Committee of İstanbul University, Cerrahpaşa Medical Faculty and written informed consent was obtained from each subject.

\section{Genetic analysis}

Genomic deoxyribonucleic acid (DNA) was isolated from frozen whole blood-EDTA according to a standard procedure. ${ }^{[16]}$ The primer sequences were used previously. ${ }^{[17]}$ Polymerase chain reaction (PCR) conditions were $96{ }^{\circ} \mathrm{C}$ for $1 \mathrm{~min}$ in all reactions, followed by 30 cycles at $94{ }^{\circ} \mathrm{C}$ for $45 \mathrm{~s}, 60{ }^{\circ} \mathrm{C}$ for $45 \mathrm{~s}, 72{ }^{\circ} \mathrm{C}$ for $45 \mathrm{~s}$ (FokI); 30 cycles at $94{ }^{\circ} \mathrm{C}$ for $1 \mathrm{~min}, 55^{\circ} \mathrm{C}$ for $1 \mathrm{~min}, 72{ }^{\circ} \mathrm{C}$ for $1 \mathrm{~min}$ (TaqI); and 30 cycles at $94{ }^{\circ} \mathrm{C}$ for $1 \mathrm{~min}, 60^{\circ} \mathrm{C}$ for $1 \mathrm{~min}, 70^{\circ} \mathrm{C}$ for $1 \mathrm{~min}$ (BsmI). All PCR products were analyzed by restriction fragment length polymorphism (RFLP) and gel electrophoresis.

\section{Statistical analysis}

Statistical analysis was performed by Epi Info Software Version 3.2.2 (CDC, Atlanta GA, USA). The distributions of BsmI, TaqI and FokI polymorphisms in the VDR gene between RA patients and healthy controls were compared using the chi-square or Fischer's exact test. $P$ value less than 0.05 was considered significant. The genotype distribution and Hardy-Weinberg equilibrium were tested with the chisquare test for quality of fit, Arlequin software version 2000, (University of Geneva, Switzerland).

\section{RESULTS}

The demographic characteristics of RA patients and healthy controls are given in Table 1 . The distributions of alleles and genotypes frequencies of BsmI, TaqI and FokI polymorphisms of VDR gene in RA and controls

\begin{tabular}{|c|c|c|c|c|c|c|}
\hline \multirow[t]{2}{*}{ Demographic features } & \multicolumn{3}{|c|}{ RA patients $(n=98)$} & \multicolumn{3}{|c|}{ Healthy controls $(n=122)$} \\
\hline & $\mathrm{n}$ & $\%$ & Mean \pm SD & $\mathrm{n}$ & $\%$ & Mean \pm SD \\
\hline Age (years) & & & $50.84 \pm 12.3$ & & & $57.1 \pm 6.1$ \\
\hline \multicolumn{7}{|l|}{ Sex } \\
\hline Female & 78 & & & 96 & & \\
\hline Male & 20 & & & 26 & & \\
\hline Patients with erosions & 51 & 69 & & & N/A & \\
\hline Patients with RF positivity & 58 & 63 & & & N/A & \\
\hline
\end{tabular}


are given in Table 2. The frequencies of $\mathrm{F}, \mathrm{T}$ and $\mathrm{B}$ allele were higher while that of the $f, t, b$ allele were lower among RA patients in comparison to controls, but no associations were found between these alleles and RA ( $\mathrm{p}=0.10,0.06$, and 0.11 , respectively). No significant differences in the distribution of the VDR genotypes between RA and controls were observed. The frequencies of BsmI, TaqI and FokI alleles/genotypes were similar among patients regardless of RF positivity and presence or absence of erosions (Table 3). There were no significant differences between the VDR genotypes/alleles and presence or absence of erosions and RF.

\section{DISCUSSION}

There have been several studies on the possible association of RA, clinical manifestations of RA, and VDR polymorphisms. The results have been controversial due to ethnicities and geographic variations. ${ }^{[8-12]}$ In addition, the age groups of the subjects and the sample sizes of these studies may account for the contradictory results. The present study evaluated for the first time the possible association of VDR polymorphisms among a group of Turkish RA patients.

\begin{tabular}{|c|c|c|c|c|}
\hline \multirow[t]{2}{*}{$\begin{array}{l}\text { Vitamin D receptor } \\
\text { locus, polymorphism }\end{array}$} & \multicolumn{2}{|c|}{$\begin{array}{l}\text { RA patients } \\
\quad(n=98)\end{array}$} & \multicolumn{2}{|c|}{$\begin{array}{l}\text { Healthy controls } \\
\qquad(n=122)\end{array}$} \\
\hline & $\mathrm{n}$ & $\%$ & $\mathrm{n}$ & $\%$ \\
\hline \multicolumn{5}{|l|}{ Fok } \\
\hline $\mathrm{F} / \mathrm{F}$ & 51 & 52 & 53 & 43 \\
\hline $\mathrm{F} / \mathrm{f}$ & 40 & 41 & 57 & 47 \\
\hline $\mathrm{f} / \mathrm{f}$ & 7 & 7 & 12 & 10 \\
\hline \multicolumn{5}{|l|}{ Allele } \\
\hline $\mathrm{F}$ & 142 & 72 & 163 & 67 \\
\hline $\mathrm{F}$ & 54 & 28 & 81 & 33 \\
\hline \multicolumn{5}{|l|}{$\mathrm{Taq}$} \\
\hline $\mathrm{T} / \mathrm{T}$ & 45 & 46 & 44 & 36 \\
\hline $\mathrm{T} / \mathrm{t}$ & 43 & 44 & 60 & 49 \\
\hline$t / t$ & 10 & 10 & 18 & 15 \\
\hline \multicolumn{5}{|l|}{ Allele } \\
\hline $\mathrm{T}$ & 133 & 68 & 148 & 61 \\
\hline $\mathrm{T}$ & 63 & 32 & 96 & 39 \\
\hline \multicolumn{5}{|l|}{ Bsm } \\
\hline $\mathrm{B} / \mathrm{B}$ & 12 & 12 & 7 & 6 \\
\hline $\mathrm{B} / \mathrm{b}$ & 46 & 47 & 60 & 49 \\
\hline $\mathrm{b} / \mathrm{b}$ & 40 & 41 & 55 & 45 \\
\hline \multicolumn{5}{|l|}{ Allele } \\
\hline B & 70 & 36 & 74 & 30 \\
\hline B & 126 & 64 & 170 & 70 \\
\hline
\end{tabular}

The study results showed that only $63 \%$ of the patients with RA were positive for RF. Similarly, in the Baran et al. ${ }^{[18]}$ study, the results were 59 percent. These results could be explained as RF may present less sensitive results in the activity of disease. Anti-CCP can be a better prognostic factor as shown in various studies. ${ }^{[19-20]}$ However, we have only the RF results as a part of our previous study.

We could not observe any association between the following BsmI, TaqI, FokI polymorphisms in VDR gene and RA with RF positivity and erosive disease of RA. These findings are parallel with previous studies conducted on the association of RA and VDR with negative results. Goertz et al. ${ }^{[1]}$ failed to show a significant association between RA susceptibility or bone turnover, family history, the presence of RF and FokI, TaqI, BsmI genotypes in VDR gene. Lee et al. ${ }^{[12]}$ observed no association with VDR TaqI, BsmI polymorphisms and RA susceptibility and bone erosion. Garcia-Lozano et al. ${ }^{[8]}$ showed no significant difference between TaqI, BsmI ApaI polymorphisms of VDR gene and RA. The study results published by Rass et al. ${ }^{[21]}$ which indicated that there was no relationship between BsmI polymorphism and RA confirms our findings in this study. However, the fact that there is a significant correlation between RF positivity and severity of RA observed in the Rass et al. study contraindicates the results of our study. ${ }^{[21]}$ In two reports, an association was found between BsmI polymorphism of the VDR gene and RA severity. ${ }^{[8-10]}$ Our results agree with the results of Gomez-Vaquero et al ${ }^{[10]}$ that reported no association between the VDR genotypes/alleles and the presence or absence of erosions and RF. Masi et al. ${ }^{[22]}$ found no relationship between RA and FokI genotype, but their results suggest that FokI polymorphism may lead to higher risk for loose bone mass. Gough et al. ${ }^{[23]}$ reported a significant association between the presence of the VDR gene $t$ allele (TaqI) in female patients with RA and accelerated bone loss. An earlier study suggested discordance between TaqI, BsmI polymorphisms and RA but a positive correlation between FokI (F allele and F/F genotype) and RA. ${ }^{[9]}$

In summary, in several studies, similar to our findings, no significant associations have been found between RA and VDR polymorphisms except for FokI polymorphism which was significantly associated with RA in a French population. ${ }^{[9]}$ These results reflect that TaqI, FokI, BsmI and ApaI polymorphisms in the VDR gene may not be responsible for the primary 


\begin{tabular}{|c|c|c|c|c|c|c|c|c|c|}
\hline \multirow{4}{*}{$\begin{array}{l}\text { Vitamin D receptor } \\
\text { locus, polymorphism }\end{array}$} & \multicolumn{4}{|c|}{ Rheumatoid factor } & \multicolumn{4}{|c|}{ Erosive disease } & \multirow[b]{4}{*}{$p$} \\
\hline & \multirow{2}{*}{\multicolumn{2}{|c|}{$\begin{array}{c}(+) \\
(\mathrm{n}=58)\end{array}$}} & \multirow{2}{*}{\multicolumn{2}{|c|}{$\begin{array}{c}(-) \\
(\mathrm{n}=34)\end{array}$}} & \multirow{2}{*}{\multicolumn{2}{|c|}{$\begin{array}{c}(+) \\
(\mathrm{n}=51)\end{array}$}} & \multirow{2}{*}{\multicolumn{2}{|c|}{$\begin{array}{c}(-) \\
(\mathrm{n}=23)\end{array}$}} & \\
\hline & & & & & & & & & \\
\hline & $\mathrm{n}$ & $\%$ & $\mathrm{n}$ & $\%$ & $\mathrm{n}$ & $\%$ & $\mathrm{n}$ & $\%$ & \\
\hline \multicolumn{10}{|l|}{ Fok } \\
\hline $\mathrm{F} / \mathrm{F}$ & 29 & 50 & 18 & 53 & 25 & 49 & 11 & 48 & \multirow{3}{*}{$0.84^{\mathrm{a}}, 0.85^{\mathrm{b}}$} \\
\hline$F / f$ & 25 & 43 & 13 & 38 & 23 & 45 & 10 & 43 & \\
\hline $\mathrm{f} / \mathrm{f}$ & 4 & 7 & 3 & 9 & 3 & 6 & 2 & 9 & \\
\hline \multicolumn{10}{|l|}{ Allele } \\
\hline $\mathrm{F}$ & 83 & 72 & 49 & 72 & 73 & 72 & 32 & 70 & \multirow{2}{*}{$0.47^{\mathrm{a}}, 0.40^{\mathrm{b}}$} \\
\hline $\mathrm{F}$ & 32 & 28 & 19 & 28 & 29 & 28 & 14 & 30 & \\
\hline \multicolumn{10}{|l|}{ Taq } \\
\hline $\mathrm{T} / \mathrm{T}$ & 26 & 45 & 16 & 47 & 28 & 55 & 12 & 52 & \multirow{3}{*}{$0.82^{a}, 0.59^{b}$} \\
\hline $\mathrm{T} / \mathrm{t}$ & 27 & 46 & 14 & 41 & 20 & 39 & 8 & 35 & \\
\hline$t / t$ & 5 & 9 & 4 & 12 & 3 & 6 & 3 & 13 & \\
\hline \multicolumn{10}{|l|}{ Allele } \\
\hline $\mathrm{T}$ & 79 & 68 & 46 & 68 & 76 & 75 & 32 & 70 & \multirow{2}{*}{$0.47^{\mathrm{a}}, 0.26^{\mathrm{b}}$} \\
\hline $\mathrm{T}$ & 37 & 32 & 22 & 32 & 26 & 25 & 14 & 30 & \\
\hline \multicolumn{10}{|l|}{ Bsm } \\
\hline $\mathrm{B} / \mathrm{B}$ & 8 & 14 & 4 & 12 & 5 & 10 & 3 & 13 & \multirow{3}{*}{$0.72^{\mathrm{a}}, 0.81^{\mathrm{b}}$} \\
\hline $\mathrm{B} / \mathrm{b}$ & 24 & 41 & 17 & 50 & 26 & 51 & 10 & 43 & \\
\hline $\mathrm{b} / \mathrm{b}$ & 26 & 45 & 13 & 38 & 20 & 39 & 10 & 43 & \\
\hline \multicolumn{10}{|l|}{ Allele } \\
\hline B & 40 & 34 & 25 & 37 & 36 & 35 & 16 & 35 & \multirow{2}{*}{$0.37^{\mathrm{a}}, 0.47^{\mathrm{b}}$} \\
\hline B & 76 & 66 & 43 & 63 & 66 & 65 & 30 & 65 & \\
\hline
\end{tabular}

disease association. Because there are controversial results in various reports, additional studies are needed to elucidate the possible association between the VDR gene and clinical features of RA including other polymorphisms in the VDR gene such as Cdx2 polymorphism. These controversial results could be due to heterogeneity between populations and the small number of samples used in the studies. Not forgetting the small sample size of our study, the present data suggests that VDR polymorphisms do not play a role either in RA susceptibility or in RF positivity and erosive disease of RA in a group of Turkish population.

\section{Acknowledgement}

The authors thank Vedat Hamuryudan for the critical review of the manuscript and the kind assistance in obtaining the patient sample.

This study was performed at İstanbul University Molecular Biology Genetics Department Human Molecular Genetics Research Laboratory and Duzen Human Genetic Disease Diagnosis Center, Molecular Genetics Laboratory.

\section{Declaration of conflicting interests}

The authors declared no conflicts of interest with respect to the authorship and/or publication of this article.

\section{Funding}

The authors received no financial support for the research and/or authorship of this article.

\section{REFERENCES}

1. Tobón GJ, Youinou P, Saraux A. Autoimmun Rev. The environment, geo-epidemiology, and autoimmune disease: Rheumatoid arthritis 2010;9:A288-92.

2. Ranganathan P. Genetics of bone loss in rheumatoid arthritis-role of vitamin $\mathrm{D}$ receptor polymorphisms. Rheumatology (Oxford) 2009;48:342-6.

3. Leventis $\mathrm{P}$, Patel S. Clinical aspects of vitamin $\mathrm{D}$ in the management of rheumatoid arthritis. Rheumatology (Oxford) 2008;47:1617-21.

4. Adorini L, Penna G. Control of autoimmune diseases by the vitamin $\mathrm{D}$ endocrine system. Nat Clin Pract Rheumatol 2008;4:404-12.

5. Andjelkovic Z, Vojinovic J, Pejnovic N, Popovic M, Dujic A, MitrovicD, etal.Disease modifying and immunomodulatory effects of high dose 1 alpha $(\mathrm{OH}) \mathrm{D} 3$ in rheumatoid arthritis patients. Clin Exp Rheumatol 1999;17:453-6. 
6. Tetlow LC, Smith SJ, Mawer EB, Woolley DE. Vitamin D receptors in the rheumatoid lesion: expression by chondrocytes, macrophages, and synoviocytes. Ann Rheum Dis 1999;58:118-21.

7. Cutolo M. Vitamin D and autoimmune rheumatic diseases. Rheumatology (Oxford) 2009;48:210-2.

8. Garcia-Lozano JR, Gonzalez-Escribano MF, Valenzuela A, Garcia A, Núñez-Roldán A. Association of vitamin D receptor genotypes with early onset rheumatoid arthritis. Eur J Immunogenet 2001;28:89-93.

9. Maalej A, Petit-Teixeira E, Michou L, Rebai A, Cornelis F, Ayadi H. Association study of VDR gene with rheumatoid arthritis in the French population. Genes Immun 2005;6:707-11.

10. Gómez-Vaquero C, Fiter J, Enjuanes A, Nogués X, Díez-Pérez A, Nolla JM. Influence of the BsmI polymorphism of the vitamin $\mathrm{D}$ receptor gene on rheumatoid arthritis clinical activity. J Rheumatol 2007;34:1823-6.

11. Goertz B, Fassbender WJ, Williams JC, Marzeion AM, Bretzel RG, Stracke H, et al. Vitamin D receptor genotypes are not associated with rheumatoid arthritis or biochemical parameters of bone turnover in German RA patients. Clin Exp Rheumatol 2003;21:333-9.

12. Lee CK, Hong JS, Cho YS, Yoo B, Kim GS, Moon HB. Lack of relationship between vitamin D receptor polymorphism and bone erosion in rheumatoid arthritis. J Korean Med Sci 2001;16:188-92.

13. Ates O, Hatemi G, Hamuryudan V, Topal-Sarikaya A. Tumor necrosis factor-alpha and interleukin-10 gene promoter polymorphisms in Turkish rheumatoid arthritis patients. Clin Rheumatol 2008;27:1243-8.

14. Ates O, Dalyan L, Müsellim B, Hatemi G, Türker H, Ongen G, et al. NRAMP1 (SLC11A1) gene polymorphisms that correlate with autoimmune versus infectious disease susceptibility in tuberculosis and rheumatoid arthritis. Int J Immunogenet 2009;36:15-9.
15. Arnett FC, Edworthy SM, Bloch DA, McShane DJ, Fries JF, Cooper NS, et al. The American Rheumatism Association 1987 revised criteria for the classification of rheumatoid arthritis. Arthritis Rheum 1988;31:315-24.

16. Miller SA, Dykes DD, Polesky HF. A simple salting out procedure for extracting DNA from human nucleated cells. Nucleic Acids Res 1988;16:1215.

17. Wilkinson RJ, Llewelyn M, Toossi Z, Patel P, Pasvol G, Lalvani $A$, et al. Influence of vitamin $D$ deficiency and vitamin D receptor polymorphisms on tuberculosis among Gujarati Asians in west London: a case-control study. Lancet 2000;355:618-21.

18. Baran I, Ateş A, Aksaray S, Toyran A, Güvener E. Association of anti-cyclic citrulinated peptide (anti-CCP) antibody with disease activity in advanced rheumatoid arthritis patients and its prognostic value. Turk Hij Den Biyol Derg 2009;66:35-47.

19. Mikuls TR, O’Dell JR, Stoner JA, Parrish LA, Arend WP, Norris JM, et al. Association of rheumatoid arthritis treatment response and disease duration with declines in serum levels of IgM rheumatoid factor and anti-cyclic citrullinated peptide antibody. Arthritis Rheum 2004;50:3776-82.

20. Bobbio-Pallavicini F, Alpini C, Caporali R, Avalle S, Bugatti S, Montecucco C. Autoantibody profile in rheumatoid arthritis during long-term infliximab treatment. Arthritis Res Ther 2004;6:R264-72.

21. Rass P, Pákozdi A, Lakatos P, Zilahi E, Sipka S, Szegedi G, et al. Vitamin D receptor gene polymorphism in rheumatoid arthritis and associated osteoporosis. Rheumatol Int 2006;26:964-71.

22. Masi L, Cimaz R, Simonini G, Bindi G, Stagi S, Gozzini A, et al. Association of low bone mass with vitamin $\mathrm{d}$ receptor gene and calcitonin receptor gene polymorphisms in juvenile idiopathic arthritis. J Rheumatol 2002;29:2225-31.

23. Gough A, Sambrook P, Devlin J, Lilley J, Huisoon A, Betteridge J, et al. Effect of vitamin D receptor gene alleles on bone loss in early rheumatoid arthritis. J Rheumatol 1998;25:864-8. 